\title{
Nymph and Adult Biology on Cultivated and on Non-Cultivated Plants and Seasonal Phenology on Wild Plants of the Neotropical Stink Bug, Euschistus paranticus Grazia (Hemiptera: Heteroptera: Pentatomidae)
}

\author{
Lisonéia F. Smaniotto ${ }^{1}$ \& Antônio R. Panizzi ${ }^{2}$ \\ ${ }^{1}$ Department of Zoology, Federal University of Paraná, Curitiba, PR, Brazil \\ ${ }^{2}$ Entomology Laboratory, Embrapa Wheat, Passo Fundo, RS, Brazil \\ Correspondence: Antônio R. Panizzi, Embrapa Wheat, P. O. Box 451, Passo Fundo, RS 99001-970, Brazil. \\ E-mail: antonio.panizzi@embrapa.br
}

Received: January 30, 2013 Accepted: March 1, 2013 Online Published: March 26, 2013

doi:10.5539/ijb.v5n2p103 URL: http://dx.doi.org/10.5539/ijb.v5n2p103

\begin{abstract}
Laboratory studies were conducted to evaluate nymph survivorship, developmental time, and fresh body weight at adult emergence, and adult survivorship, total longevity, reproduction, and fresh body weight gain of the Neotropical stink bug, Euschistus paranticus Grazia (Heteroptera: Pentatomidae). In the field, a one-year weekly survey was carried out on the wild plants, Scutia buxifolia Reissek (Rhamanaceae) and Prunus myrtifolia (L.) Urb. (Rosaceae) in Passo Fundo, RS, Brazil (28 $15^{\prime}$ S latitude; $52^{\circ} 24^{\prime} \mathrm{W}$ longitude). Results indicated that nymph mortality was very high (range $87-100 \%$ ) and on only two (green bean pod + raw shelled peanut and green bean pod alone) out of the nine foods, nymphs were able to complete development. Nymph developmental time ( $2^{\text {nd }}$ to $5^{\text {th }}$ stadia) took $\approx 33$ days on green bean pod + peanut seed, and $\approx 54$ days on green bean pod. Adults $E$. paranticus fed pods of green bean, raw shelled peanut, mature seed of soybean, and leaf of $S$. buxifolia in the laboratory showed a total longevity of $\approx 40$ to 55 days; $50 \%$ females oviposited; the pre-oviposition period was 18.9 days; number of egg masses/female was 9.3; mean total number of eggs/female was 103.6, and their viability was $55.6 \%$. Females were heavier than males. E. paranticus was intercepted mostly during spring-summer on S. buxifolia, and only occasionally on P. myrtifolia.
\end{abstract}

Keywords: stink bug, biology, host plants, phenology

\section{Introduction}

Within the genus Euschistus, the sub-genus Mitripus (Heteroptera: Pentatomidae) was proposed by Rolston (1978) to accommodate seven South American species. Grazia (1987) described and included in this sub-genus two new species E. (M.) hansi and E. (M.) paranticus. More recently, Bunde, Grazia,, and Mendonça Jr. (2006) added a new species to this group $E$. (M.) irroratus.

While surveying pentatomids at the Embrapa Wheat field experiment station at Passo Fundo, RS $\left(28^{\circ} 15^{\prime} \mathrm{S}\right.$ latitude; $52^{\circ} 24^{\prime} \mathrm{W}$ longitude) in 2011, we intercepted adult specimens of Euschistus paranticus Grazia on two wild plants, on Scutia buxifolia Reissek (Rhamanaceae), locally known as 'coronilha', and on Prunus myrtifolia (L.) Urb. (Rosaceae) known as wild peach tree ('pessegueiro-bravo'). Not much was found in the literature regarding this uncommon Neotropical stink bug, except for the capture of 12 specimens on wild vegetation using a sweep net at Canguçu County $\left(31^{\circ} 05^{\prime} \mathrm{S}\right.$ and $\left.52^{\circ} 50^{\prime} \mathrm{W}\right)$ and at Barra do Quaraí County $\left(30^{\circ} 11^{\prime} \mathrm{S}\right.$ and $57^{\circ} 30^{\prime} \mathrm{W}$ ) during 2003-2004 (Bunde et al., 2010); and 2 specimens on wild vegetation at the Turvo State Park $\left(27^{\circ} 00^{\prime} \mathrm{S}\right.$ and $\left.53^{\circ} 40^{\prime} \mathrm{W}\right)(2004-2005)$ (Schmidt \& Barcellos, 2007), all in Rio Grande do Sul state, Brazil. This group of stink bugs of the sub-genus Mitripus is mostly restricted to the north of Argentina, Uruguay and southern Brazil (Bunde et al., 2006) and their biology is practical unknown.

Because of the lack of data on the biology of E. paranticus we decided to carry on laboratory studies on nymph development and adult reproduction. We tested the common foods used to rear other species of pentatomids, and also tested vegetative and reproductive plant parts of one of the wild plants they were found on ('coronilha'). 
In the field, a survey was systematically conducted on the two species of wild plants they were intercepted, in order to elucidate the phenology of the bugs around the year.

\section{Materials and Methods}

\subsection{Insect Colony}

During September-November 2011, adults of E. paranticus were field-collected by shaking the branches over a plastic white cloth of the two wild plants, Scutia buxifolia Reissek (Rhamanaceae), and Prunus myrtifolia (L.) Urb. (Rosaceae) at the Embrapa Wheat field experiment station at Passo Fundo, RS, Brazil $\left(28^{\circ} 15^{\prime} \mathrm{S}\right.$ latitude; $52^{\circ} 24^{\prime} \mathrm{W}$ longitude). Adults were taken to the laboratory and placed in clear plastic rearing boxes $(25 \times 20 \times 20$ $\mathrm{cm}$ ), lined with filter paper and provided with pods of green bean, Phaseolus vulgaris L., raw shelled peanut, Arachis hypoagea L., mature seeds of soybean, Glycine max (L.), fruits (berries) of privet, Ligustrum lucidum Ait., and fruits and leaves of a small branch of $S$. buxifolia placed in a vial with water. Boxes were kept in a walk-in chamber at $25 \pm 1{ }^{\circ} \mathrm{C}$ temperature, $65 \pm 5 \% \mathrm{RH}$ and a photoperiod of $14: 10 \mathrm{~h}$ (L:D). Food was checked daily, and replaced when necessary. The colony was revigorated every week with the addition of field-collected adults, and nymphs obtained were raised to reach the adult stage.

\subsection{Nymph Study}

From the colony established in the laboratory, egg masses were collected daily. They were placed in clear plastic boxes $(11 \times 11 \times 3.5 \mathrm{~cm})$ lined with filter paper, containing a wet cotton ball in a round plastic lid to avoid egg desiccation. They were kept in an environmental chamber $\left(25 \pm 1^{\circ} \mathrm{C}, 65 \pm 5 \% \mathrm{RH}\right.$, and $14 \mathrm{hrs}$ photophase). As nymphs emerged they were kept untouched, and when they molted to the $2^{\text {nd }}$ instar $\left(1^{\text {st }}\right.$ instar do not feed $)$, they were placed singly in plastic Petri dish $(9.0 \times 1.5 \mathrm{~cm})$ lined with filter paper and containing wet cotton as in the plastic boxes. Thirty nymphs were fed with one of the following food sources: green bean pod+raw shelled peanut; green bean pod; raw shelled peanut; green bean pod + raw shelled peanut + privet fruit; privet fruit; wheat seed mature; soybean seed mature; "coronilha" fruit; and "coronilha" leaf. Food was changed every other day, and nymphs were checked daily for mortality and possible molt. Nymph developmental time and mortality (\%) at each instar (not included the $1^{\text {st }}$ instar) and from the $2^{\text {nd }}$ to the $5^{\text {th }}$ instar was calculated. Fresh body weight was measured for those nymphs that reached adulthood at the day of adult emergence. Data were analyzed using the analysis of variance (ANOVA) and means compared using the Tukey's test for more than two means or using the $t$-test to compared paired means $(\mathrm{P} \leq 0.05)$ using the statistic program SAS 8.2 (SAS Institute, 1981).

In order to avoid a possible negative effect of raising nymphs in isolation, a second test was run with nymphs placed in groups in clear plastic boxes $(11 \times 11 \times 3.5 \mathrm{~cm})$ lined with filter paper $(\mathrm{n}=10 \mathrm{nymphs} / \mathrm{box})$ using a mixture of diets (green bean pod, raw shelled peanut, privet fruit; "coronilha" fruit; and "coronilha" leaf). Five boxes were used. Nymphs that reached the adulthood were recorded and the percentage of nymphs that completed development was calculated.

\subsection{Adult Study}

Adults were obtained from the laboratory colony, which was set as previously described. On the day of adult emergence, 20 females and 20 males were selected, and each pair was placed in clear plastic boxes $(11 \mathrm{x} 11 \mathrm{x}$ $3.5 \mathrm{~cm})$ lined with filter paper. They were kept in an environmental chamber $\left(25 \pm 1^{\circ} \mathrm{C}, 65 \pm 5 \% \mathrm{RH}\right.$, and $14 \mathrm{hrs}$ photophase). From the previous study with nymphs, we noticed that they were not able to reach the adult stage on the majority of the foods tested. In addition, not enough adults were obtained to test their biology on each food used for the nymphs. Therefore, we decided to test for adults a mixture of the previous foods i.e., pods of green bean, raw shelled peanut, mature seeds of soybean, and leaves of $S$. buxifolia attached to a branch and placed in a vial with wet cotton. A cotton commercial ball was used to receive the egg masses, since this has been successfully used to accommodate egg masses of several species of pentatomids (Silva \& Panizzi, 2007, 2009). Daily observations were made to check for adult survival and reproduction. After all adults' death, we calculated their survivorship, total longevity, percentage females that oviposited, pre-oviposition period, number of eggs masses and eggs laid, and egg hatchability (fertility). Also we calculated fresh body weight gain weekly up to the $4^{\text {th }}$ week (day 28) of adult life. Data on total longevity and on fresh body weight gain of females vs. males were compared using the analysis of variance (ANOVA) and means compared using the Tukey's test for more than two means or using the $t$-test to compared paired means $(\mathrm{P} \leq 0.05)$ using the statistic program SAS 8.2 (SAS Institute 1981).

\subsection{Field Survey}

From September 2011 to August 2012, a field survey of E. paranticus was conducted at the Embrapa Wheat field experiment station in Passo Fundo, RS (28 $15^{\prime} \mathrm{S}$ latitude; $52^{\circ} 24^{\prime} \mathrm{W}$ longitude). Earlier explorations 
indicated the presence of the bugs on two different species of native grown trees. Therefore, we selected two plants, one of the species Scutia buxifolia Reissek (Rhamanaceae), locally known as 'coronilha', and the other of the species Prunus myrtifolia (L.) Urb. (Rosaceae) known as wild peach tree ('pessegueiro-bravo') to be examined. Samples were taken on a weekly basis. Each sample consisted of shaking for 2 minutes the lower branches of the trees on the top of a white plastic cloth $(1.5 \times 1.5 \mathrm{~m})$ placed under the foliage. Falling insects were collected and their number recorded. Data from each plant were plotted in graph using the program Excel 2010.

\section{Results and Discussion}

\subsection{Nymph Study}

Survivorship and developmental time of nymphs was affected by the different food sources utilized. In general, nymph mortality was very high, and on only two out of the nine foods, nymphs were able to complete development (Table 1). These were green bean pod + raw shelled peanut and green bean pod alone (mortality range $87-90 \%$ ); on the remaining foods no nymphs reached adulthood. Nymphs reached the $4^{\text {th }}$ instar on peanuts, and on the mixture green bean pod + peanut + privet; nymphs reached the $3^{\text {rd }}$ instar on privet and on wheat seed; nymphs completed the $2^{\text {nd }}$ instar on soybean seed and on "coronilha" fruit; and no nymphs completed the $2^{\text {nd }}$ instar on 'coronilha' leaf. When nymphs were raised in groups using a mixture of diets (green bean pod, raw shelled peanut, privet fruit, 'coronilha" fruit, and 'coronilha' leaf) the total mortality was still very high (mean \pm SEM \% of $92.4 \pm 2.32$ ). These data on nymph mortality are in general much higher compared to those of several species of pentatomids raised in the laboratory (references in Panizzi, 1997). For example, nymph mortality of the common Neotropical brown stink bug, Euschistus heros (F.), varies from $\approx 20$ to $25 \%$ (Villas Bôas \& Panizzi, 1980; Pinto \& Panizzi, 1994). Eventually mortality can reach over $90 \%$ as for the brown stink bug, Euschistus servus (Say) feeding on wild host in the USA (Jones, 1979). We suspect that the main reason for the high mortality observed might be due to the fact that none of the foods tested are explored by E. paranticus in nature. In fact, throughout the survey period of one year, nymphs were never captured in the field. Despite the relative abundance of adults, in particular on the wild host 'coronilha', no egg masses or nymphs were observed on that plant. Certainly, nymphs develop on other host plants which are, up to this moment, unknown.

Nymph developmental time ( $2^{\text {nd }}$ to $5^{\text {th }}$ stadia) took $\approx 33$ days on green bean pod + peanut seed, and $\approx 54$ days on green bean pod (Table 1). These were the only foods on which nymphs were able to complete development. The time to complete the $2^{\text {nd }}$ stadium was greatly variable ( 8.6 to 24.1 days); a similar situation was observed for the $3^{\text {rd }}$ (6.0 to 18.5 days) and $4^{\text {th }}$ stadia ( 8.0 to 15.0 days). For the $5^{\text {th }}$ stadium this range was less pronounced ( 8.0 to 10.3 days). During the $2^{\text {nd }}$ stadium, nymphs took less time to complete development when fed on soybean, on peanut or on wheat seed (8.6 to 9.4 days); longer time was taken on 'coronilha' and on privet fruit (18.2 and 24.1 days); on the remaining foods the values were intermediate (Table 1). During the $3^{\text {rd }}$ stadium, the shortest time to complete development occurred on wheat seed (6 days), although just one nymph passed to the following stadium on this food; on the remaining foods time of development was variable ( $\approx 10$ to 18 days) but not significantly different, with nymphs on green bean pod + peanut showing the lowest value. During the $4^{\text {th }}$ and $5^{\text {th }}$ stadia, nymphs took less time to complete development on green bean pod + peanut. These data on time of development demonstrate that these last two foods when offered in conjunction yielded the best results. Green bean pod + peanut have been used to rear different species of stink bugs in the laboratory worldwide since the 1980's (Harris \& Todd, 1980, 1981; Brewer \& Jones, 1985; Jones, 1985). The fact that no nymphs survived the $2^{\text {nd }}$ instar on 'coronilha' leaf, adds another record to the already known inability of pentatomid nymphs to even partially develop on vegetative tissues (Panizzi \& Slansky, 1991).

Fresh body weight at adult emergence of the few bugs that completed development was significantly greater for females fed green bean pod + peanut than those solely fed on green bean pod (Table 2). Females were significantly heavier than males, which is common among pentatomids (Panizzi \& Slansky, 1991). 
Table 1. Mean ( \pm SEM) nymph developmental time and mortality [\%] at each instar and total $\left(2^{\text {nd }}\right.$ to $5^{\text {th }}$ instar $)$ of Euschistus paranticus feeding on different food sources in the laboratory (number of individuals in parentheses; initial number of nymphs $=30$ )

\begin{tabular}{llllll}
\hline \multirow{2}{*}{ Food source } & \multicolumn{5}{c}{ Duration of nymph stadia (days) } \\
\cline { 2 - 6 } & $2^{\mathrm{o}}$ & $3^{\mathrm{o}}$ & $4^{\mathrm{o}}$ & $5^{\mathrm{o}}$ & $2^{\mathrm{o}}-5^{\mathrm{o}}$ \\
\hline Green bean pod + & $11.9 \mathrm{bcd}$ & $10.4 \mathrm{a}$ & $8.0 \mathrm{a}$ & $8.0 \mathrm{a}$ & $32.7 \mathrm{~b}$ \\
peanut seed & $( \pm 1.08)$ & $( \pm 1.68)$ & $( \pm 2.59)$ & $( \pm 1.47)$ & $( \pm 1.65)$ \\
& $(16)[46.7]$ & $(8)[73.3]$ & $(5)[83.3]$ & $(4)[86.67]$ & $(4)[86.7]$
\end{tabular}

Green bean pod

$\begin{array}{lllll}14.2 \mathrm{bc} & 13.1 \mathrm{a} & 12.7 \mathrm{a} & 10.3 \mathrm{a} & 54.3 \mathrm{a} \\ ( \pm 1.04) & ( \pm 0.99) & ( \pm 1.37) & ( \pm 2.67) & ( \pm 3.33) \\ (23)[23.3] & (16)[46.7] & (7)[76.7] & (3)[90.0] & (3)[90.0]\end{array}$

Peanut seed

$\begin{array}{lll}8.9 \mathrm{~d} & 13.4 \mathrm{a} & 15.0 \mathrm{a} \\ ( \pm 0.56) & ( \pm 2.04) & ( \pm 0.00) \\ (15)[50.0] & (9)[70.0] & (2)[96.7]\end{array}$

Green bean pod + peanut + privet

$\begin{array}{lll}13.0 \mathrm{bcd} & 12.7 \mathrm{a} & * 10.0 \\ ( \pm 0.67) & ( \pm 1.96) & (-) \\ (12)[60.0] & (7)[76.7] & (1)[96.7]\end{array}$

$[100]$

[100]

Privet fruit

$\begin{array}{lll}24.1 \mathrm{a} & 18.5 \mathrm{a} & - \\ ( \pm 3.06) & ( \pm 7.50) & {[100]} \\ (8)[73.3] & (2)[93.3] & \end{array}$

100]

[100]

Wheat seed

$\begin{array}{ll}9.4 \mathrm{~cd} & * 6.0 \\ ( \pm 0.84) & (-) \\ (8)[73.3] & (1)[96.7]\end{array}$

[100]

[100]

Soybean seed

$8.6 \mathrm{~d}$
$( \pm 1.05)$
$(8)[73.3]$

[100]

[100]

'Coronilha' fruit

$\begin{array}{ll}18.2 \mathrm{ab} & - \\ ( \pm 3.60) & {[100]} \\ (4)[86.7] & \end{array}$

'Coronilha' leaf

[100] $-$ [100]

${ }^{1} \overline{\text { Means followed by the same letter in each column do not differ significantly using the Tukey's test }(\mathrm{P} \leq 0.05)}$. *Data with a single value were excluded from the statistical analysis. 
Table 2. Mean ( \pm SEM) fresh body weight of Euschistus paranticus feeding on different food sources in the laboratory (number of individuals in parentheses)

\begin{tabular}{lcc}
\hline \multirow{2}{*}{ Food source } & \multicolumn{2}{c}{ Fresh body weight $(\mathrm{mg})^{1}$} \\
\cline { 2 - 3 } & Female & Male \\
\hline Green bean pod + peanut seed & $63.0 \pm 12.25 \mathrm{a} \mathrm{A}$ & $(2)$ \\
Green bean pod & $(2)$ & $* 36.3 \pm 9.00 \mathrm{~B}$ \\
& $45.5 \pm 9.89 \mathrm{a}$ & $(1)$
\end{tabular}

${ }^{1}$ Means followed by the same lower case letter in the column and upper case letter in the line do not differ significantly using the $t$-test $(\mathrm{P} \leq 0.05)$. *Data with a single value were excluded of the statistical analysis.

\subsection{Adult Study}

Adults E. paranticus fed pods of green bean, raw shelled peanut, mature seeds of soybean, and leaves of $S$. buxifolia in the laboratory survived over 80 days (Figure 1). At each 10 days intervals of survival evaluation, males always showed greater survival values than females. Total longevity, although not significantly different, tended to be greater for males compared to females. The total longevity values (range $\approx 40$ to 55 days) are similar to the total longevity recorded for another species of Euschistus (E. heros) feeding on a wild plant (41.8-62.2 days) (Panizzi \& Rossi, 1991), and shorter than those recorded for the same bug feeding on soybean (71.8-119.9 days (Villas, Bôas, \& Panizzi, 1980).

From the 20 couples observed, 10 (50\%) oviposited. The pre-oviposition period was $18.9 \pm 3.88$ days. The mean $( \pm$ SEM) number of egg masses laid by those females that oviposited was $9.3 \pm 2.87$; mean total number of eggs reached $103.6 \pm 31.50$, and their viability (fertility) was 55.6 \pm 11.34 . Considering that the host plants where the bugs reproduce in nature are unknown, results obtained with the diet commonly used in the laboratory to raise several species of pentatomids were satisfactory. This was possible because pentatomids are in general polyphagous, feeding on an array of plants (Panizzi, McPherson, James, Javahery, \& McPherson, 2000). However, should the preferred host plants of E. paranticus be found, a much better reproductive performance is to be expected.

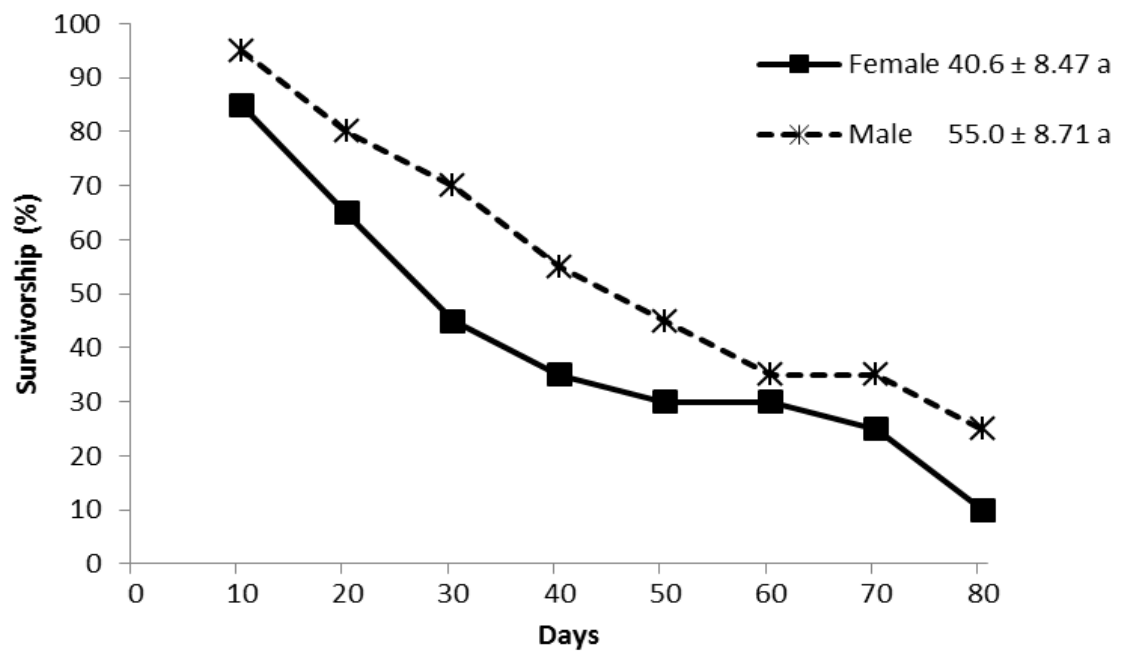

Figure 1. Survivorship and total longevity (days) of adult Euschistus paranticus feeding on pods of green bean, raw shelled peanut, mature seed of soybean, and leaf of Scutia buxifolia in the laboratory. Means followed by the same letter do not differ significantly using the $t$-test $(\mathrm{P} \leq 0.05)$

Adult females fed on the mix natural diet tested (pods of green bean, raw shelled peanut, mature seeds of soybean, and leaves of $S$. buxifolia) gained fresh body weight during the first week of adult life, and then it 
leveled off (Figure 2). Adult males showed a similar pattern of weight gain, but less pronounced. Females were significantly heavier than males. In general, body weight gain of pentatomids occurs during the first 1-2 weeks of adult life and is greater for females (Kester, 1983; Panizzi \& Meneguim, 1989; Panizzi \& Slansky, 1991).

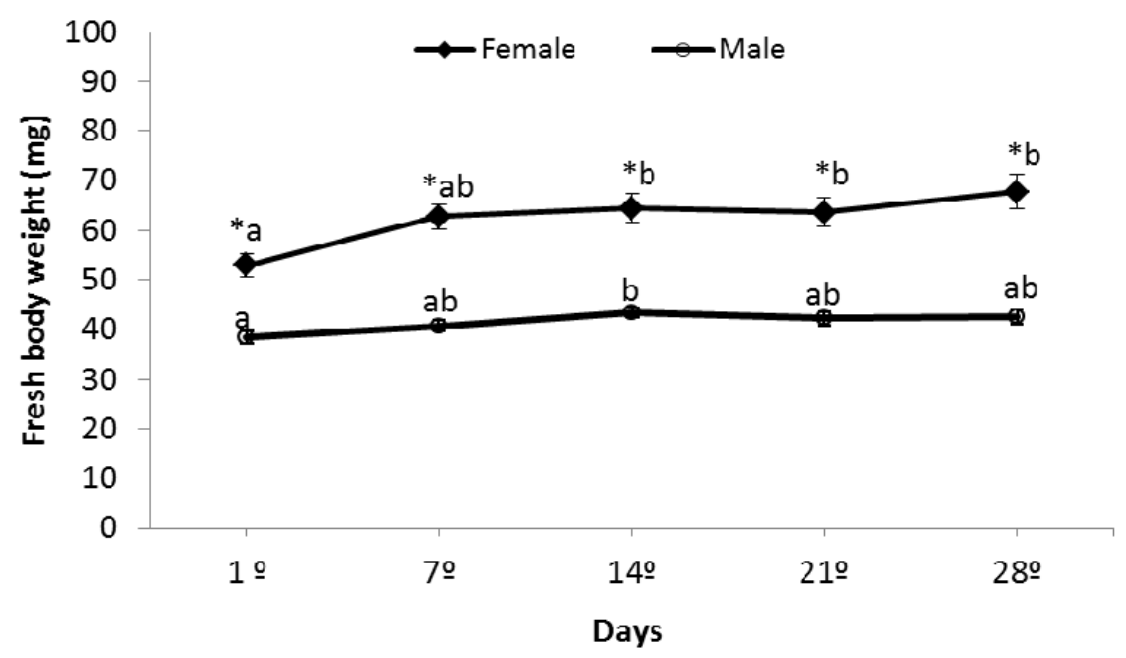

Figure 2. Fresh body weight of adult Euschistus paranticus feeding on pods of green bean, raw shelled peanut, mature seed of soybean, and leaf of Scutia buxifolia in the laboratory

Means followed by the same letter do not differ significantly using the Tukey's test $(\mathrm{P} \leq 0.05)$. Asterisk (*) indicates significant difference between genders at each time period using the $t$-test $(\mathrm{P} \leq 0.05)$.

\subsection{Field Survey}

The seasonal phenology of adult E. paranticus during a one-year period (September 2011-August 2012) on the wild host plant 'coronilha' Scutia buxifolia Reissek (Rhamanaceae) at the Embrapa Wheat field experiment station in Passo Fundo, RS, Brazil, indicated a peak in the population (13 to16 adults/sample) at the beginning of spring during September (Figure 3).

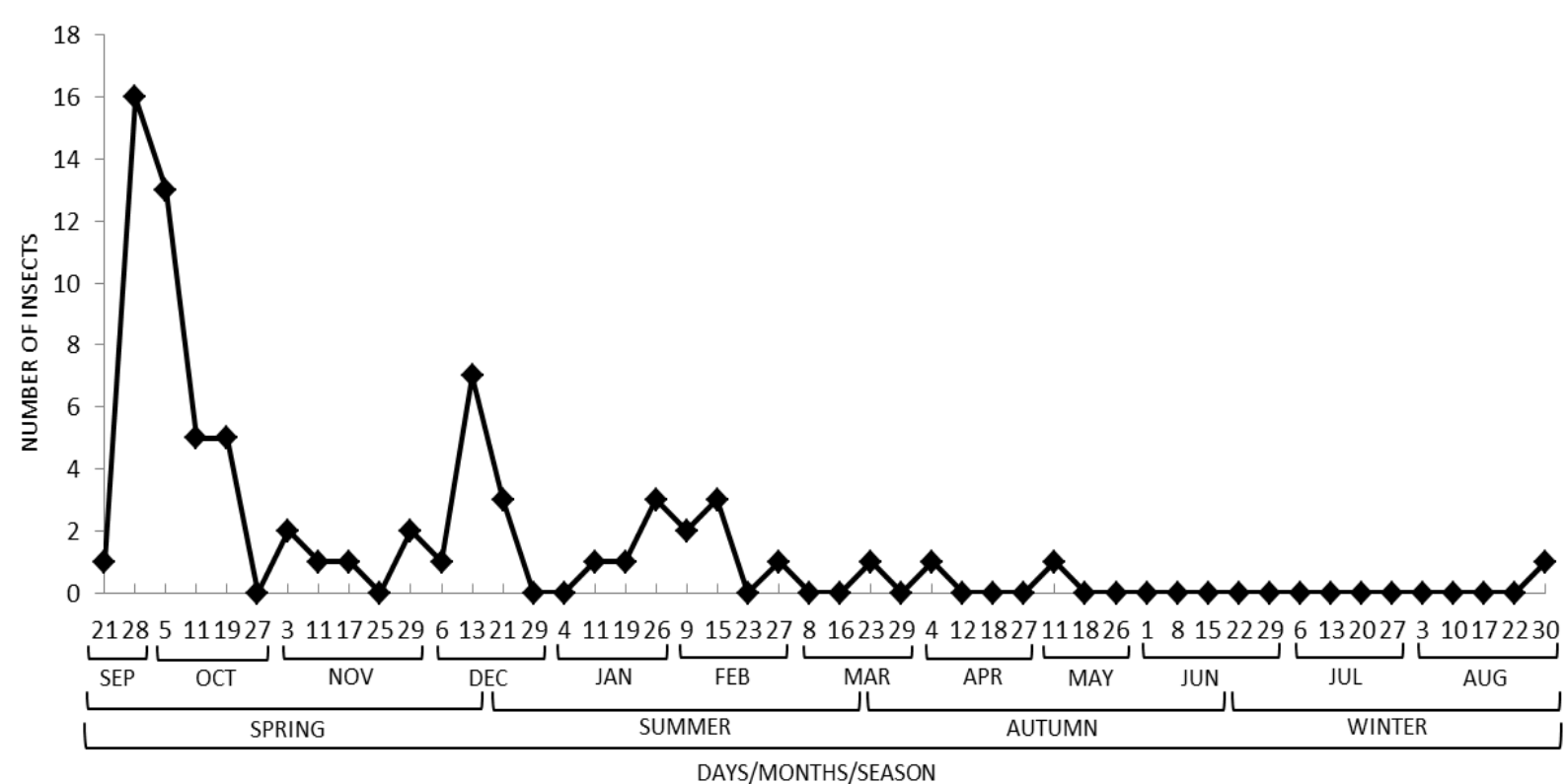

Figure 3. Seasonal phenology of adult Euschistus paranticus during one year period (September 2011-August 2012) on the wild host plant 'coronilha' Scutia buxifolia Reissek (Rhamanaceae) at the Embrapa Wheat field experiment station in Passo Fundo, RS, Brazil ( $28^{\circ} 15^{\prime} \mathrm{S}$ latitude; $52^{\circ} 24^{\prime} \mathrm{W}$ longitude) 
A decrease in the number of bugs intercepted was observed thereafter throughout the spring toward the end of the summer (October-March) (range 1-7 bugs/sample); very few bugs were captured during autumn/winter (April-August) (mean of $<1 \mathrm{bug} / \mathrm{sample}$ ). On the second species of plant surveyed Prunus myrtifolia (L.) Urb. (Rosaceae) known as wild peach tree ('pessegueiro-bravo'), only during January adult E. paranticus were intercepted (mean number of $\approx 18$ adults/sample). Surprisingly, no bugs were captured thereafter. Apparently, these bugs move to the wild peach at random. No nymphs were captured during the entire period of sampling, and no egg masses were observed on any of the two wild plant species examined.

These results on the phenology of E. paranticus on these two wild plants suggest that they cannot be considered host plants. This is because nymphs were not observed colonizing them, and no reproduction of bugs fed with fruit/leaf of them occurred in the laboratory. Apparently, adults feed on these two species of plants temporarily and/or use them for shelter, and utilize other food sources for reproduction. Data from the literature on their occurrence on other host plants (Schmidt \& Barcellos, 2007; Bunde et al., 2010) refer to adult occurrence in a similar way, and do not mention reproduction of E. paranticus. Clearly, further investigation is needed to identify food sources utilized by nymphs to complete development, and to identify plants on where adults lay egg masses.

In conclusion, data from these laboratory and field studies demonstrate that the uncommon Neotropical stink bug, E. paranticus is able to complete development and reproduce on a mix of natural diets commonly used to rear stink bugs in the laboratory. Adult phenology on the wild plant 'coronilha' indicates they explore this plant particularly during spring-summer as food source and/or shelter.

\section{Acknowledgments}

We thank Jocélia Grazia for insect identification, João A. Jarenkow for plant identification, and Egídio Sbrissa for assistance with the field survey. This research was supported by a scholarship to LFS from CAPES and by a research project process number 470920/2010-6 to ARP by the National Research Council for Scientific and Technological Development (CNPq) of Brazil. This paper was approved for publication by the Editorial Board of Embrapa Wheat, protocol number 4903/2013.

\section{References}

Brewer, F. D., \& Jones, W. A. Jr. (1985). Comparison of meridic and natural diets on the biology of Nezara viridula (Heteroptera: Pentatomidae) and eight other phytophagous Heteroptera. Annals of the Entomological Society of America, 78, 620-625.

Bunde, P. R. S., Grazia, J., \& Mendonça Jr., M. S. (2006). Nova espécie de Euschistus (Mitripus) da Argentina e do sul do Brasil (Hemiptera, Pentatomidae, Pentatominae). Iheringia, Série Zoologia, 96, 289-291.

Bunde, P. R. S., Grazia, J., Mendonça Jr., M. S., Schwertner, C. F., Silva, E. J. E., \& Garcia, E. N. (2010). Pentatomidae (Hemiptera: Heteroptera) of the Pampa biome: Serra do Sudeste and Parque de Espinilho da Barra do Quarai, Rio Grande do Sul, Brazil. Biota Neotropica, 10, 83-88. http://dx.doi.org/10.1590/S1676-06032010000300008

Grazia, J. (1987). Duas novas espécies de Euschistus do subgênero Mitripus Rolston, 1978 (Heteroptera, Pentatomidae, Pentatomini). Revista Brasileira de Entomologia, 31, 83-88.

Harris, V. E., \& Todd, J. W. (1980). Duration of immature stages of the southern green stink bug, Nezara viridula (L.), with a comparative review of previous studies. Journal of the Georgia Entomological Society, $1,114-124$.

Harris, V. E., \& Todd, J. W. (1981). Rearing the southern green stink bug, Nezara viridula, with relevant aspects of its biology. Journal of the Georgia Entomological Society, 16, 203-210.

Jones Jr., W. A. (1979). The distribution and ecology of pentatomids pests of soybeans in South Carolina (Ph. D. thesis). Clemson, SC: Clemson University.

Jones Jr., W. A. (1985). Nezara viridula. In P. Singh \& R. F. Moore (Eds.), Handbook of Insect Rearing (pp. 339-343). New York, NY: Elsevier.

Kester, K. (1983). The southern green stink bug, Nezara viridula (L.): growth, development, nutrition, and mechanism of resistance in soybean (Glycine max (L.) Merrill) genotype PI 171444 (MS. Thesis). Baton Rouge, LA: Louisina State University.

Panizzi, A. R. (1997). Wild hosts of pentatomids: ecological significance and role in their pest status on crops. Annual Review of Entomology, 42, 99-122. 
Panizzi, A. R., \& Meneguim, A. M. (1989). Performance of nymphal and adult Nezara viridula (Hemiptera: Pentatomidae) on selected overwintering host plants. Entomologia Experimentalis et Applicatta, 50, 215-223.

Panizzi, A. R., \& Rossi, C. E. (1991). The role of Acanthospermum hispidum (Compositae) in the phenology of Euschistus heros and of Nezara viridula (Heteroptera: Pentatomidae). Entomologia Experimentalis et Applicatta, 59, 67-74.

Panizzi, A. R., \& Slansky, F. Jr. (1991). Suitability of selected legumes and the effect of nymphal and adult nutrition in the southern green stink bug (Hemiptera: Heteroptera: Pentatomidae). Journal of Economic Entomology, 84,103-113.

Panizzi, A. R., McPherson, J. E., James, D. G., Javahery, M., \& McPherson, R. M. (2000). Economic importance of stink bugs (Pentatomidae). In Schaefer, C. W. \& Panizzi, A. R. (Eds.), Heteroptera of Economic Importance (pp. 421-474). Boca Raton, FL: CRC Press.

Pinto, S. B., \& Panizzi, A. R. (1994). Performance of nymphal and adult Euschistus heros (F.) on milkweed and on soybean and effect of food switch on adult survivorship, reproduction and weight gain. Anais da Sociedade Entomológica do Brasil, 23, 549-555.

Rolston, L. H. (1978). A new subgenus of Euschistus (Hemiptera: Pentatomidae). Journal of the New York Entomological Society, 86, 102-120.

SAS Institute. (1981). SAS for linear models. A guide to the ANOVA and GLM procedures. SAS Institute, Cary, N.C.

Schmidt, L. S., \& Barcellos, A. (2007). Abundância e riqueza de espécies de Heteroptera (Hemiptera) do Parque Estadual do Turvo, sul do Brasil: Pentatomoidea. Iheringia, Série Zoologia, 97, 73-79.

Silva, F. A. C., \& Panizzi, A. R. (2007). Cotton balls as an oviposition substrate for laboratory rearing of phytophagous stink bugs (Heteroptera: Pentatomidae). Annals of the Entomological Society of America, 100, 745-748.

Silva, F. A. C., \& Panizzi, A. R. (2009). Oviposition of the neotropical brown stink bug Euschistus heros (Heteroptera: Pentatomidae) on artificial and on natural substrates. Florida Entomologist, 92, 513-515.

Villas Bôas, G. L., \& Panizzi, A. R. (1980). Biologia de Euschistus heros (Fabricius, 1978) em soja (Glycine $\max (\mathrm{L}$.$) Merrill). Anais da Sociedade Entomológica do Brasil, 9, 105-113.$ 